\title{
An Empirical Study of Investors' Disposition Effect in China Based on Open Data from the Chinese Stock Markets
}

\author{
Huan Cai ${ }^{1}$, Meining Wang ${ }^{1} \&$ Chaonan Bai $^{2}$ \\ ${ }^{1}$ School of English for International Business, Guangdong University of Foreign Studies, Guangzhou, China \\ ${ }^{2}$ Deloitte \& Touche Financial Advisory Services Ltd \\ Correspondence: Meining Wang, School of English for International Business, Guangdong University of \\ Foreign Studies, Guangzhou, China. Tel: 86-20-3620-9305. E-mail: 199210407@ oamail.gdufs.edu.cn
}

Received: March 16, 2018

Accepted: April 10, 2018

Online Published: April 15, 2018

doi:10.5539/ijef.v10n5p165

URL: https://doi.org/10.5539/ijef.v10n5p165

\begin{abstract}
This paper focuses on investors' different behavioral biases in China's segmented stock markets and investigates the correlation between average holding periods, stock returns and investors' disposition effect between 2010 and 2014. The results show that the disposition effect is prevalent in A-share market but is very weak in Growth Enterprise market and there is a lack of evidence to support the existence of disposition effect in B-share market. The study supports the view that investors' experience and sophistication can partly help reduce investors' behavioral biases in stock markets. It also indicates that investors in A-shares market prefer to hold stocks with larger market capitalization for longer periods, while investors of B-shares markets and Growth Enterprise market do not reveal a specific preference for market capitalization.
\end{abstract}

Keywords: investors' behavior, disposition effect, investment experience

\section{Introduction}

\subsection{Research Background}

One hypothesis that still enjoys wide currency in finance is that markets will be efficient if investors are rigorously rational. However, the rigorous rationality of all the investors in reality is open to increasing doubt and we now realize that investors' behavioral biases can render the trading patterns inconsistent. This paper focuses on one such bias, that is, investors' reluctance to realize losing stocks and tendency to realize gaining stocks too soon, or what Shefrin and Statman (1985) call the disposition effect.

In recent years, behavioral finance has become an increasingly popular subject among economists and investors' behavioral biases are receiving more and more attention from researchers. As a radical shift from the traditional finance theory and also a challenge to the traditional investment decision-making models, behavioral finance presupposes that investors are irrational, which effectively attempts to shake the traditional theoretical foundations of finance. Behavioral finance recognizes that investors usually tend to make decisions based on their experience or instinct rather than their rationality (Kahneman \& Tversky, 1979; Hogarth \& Reder, 1987; Tversky \& Kahneman, 1992). From the study of experimental psychology, we know that human beings are loss averse and are more sensitive to loss than to the same degree of gain.

With of its growth, behavioral finance has become both theoretically and practically meaningful and useful to the prediction of investors' behaviors. Although traditional finance theory is still dominant in the current research into investment decision, most of the assumptions of behavioral finance are irrational, or at least realistic, which is of great academic and practical value in the study of investors' behaviors.

Previous researches by Visaltanachoti, Luo, and Lu (2007) and Chi and Zhuang (2011) have both explored investors' behavioral biases in the Chinese stock markets. They have studied the disposition effect of Chinese investors in both A-shares market and B-shares market in different time periods. Some of their results are similar while others are different. Both studies find that the disposition effect seems to be vague in B-shares market, but what distinguish the two is that in Visaltanachoti, Luo, and Lu's (2007) study, the disposition effect is prevalent in A-shares market through 1996 to 2003 while Chi and Zhuang (2011) indicate that the opposite of such effect in A-shares market seems to be at work since 2006 because of the split-share structure reform. As there has been no recent research on the disposition effect in the past few years, it would be interesting to study its latest development 
and to see what changes may have happened to Chinese investors.

\subsection{Research Questions}

This paper adopts the Generalized Least Squares (GLS) method by employing a large sample of publicly listed Chinese firms from year 2010 and 2014, and studies China's A-Share, B-Share and Growth Enterprise market, The following issues are examined: (1) Do market capitalization, returns, return volatility and turnover rate all directly influence the investors' holding periods? (2) Does the disposition effect still exist in the Chinese stock markets? (3) What are the probable reasons that drive the investing behavior different in the segmented markets?

\subsection{Original Contribution of This Study}

Much of this research design is modeled on the study of Chi and Zhuang (2011). This paper extends their study by adding a new segmented market, i.e., Growth Enterprise market, into the analysis of the causes of disposition effect. Growth enterprise market is a second-board market established to address the financing need of entrepreneurial enterprise, small and medium-sized enterprises and high-tech enterprises. It is different from the main-board market and its listing requirements are less strict. Thus, there are more price fluctuations and risks in Growth Enterprise market than those in A-shares and B-shares market. And it is also regulated in China that investors should have at least two years of transaction experience before they can trade in Growth Enterprise market. Therefore, to examine the disposition effect in Erowth Enterprise market is of huge importance to discuss the influence of investor sophistication and experience on their trading behaviors.

The remainder of the paper is organized as follows. Section two is a literature review of the main theories related to the disposition effect. Section three illustrates the source of data and explains how the holding period is measured. In this section, we will also define the model to be applied in studying the factors that will influence the holding period. Section four offers summary statistics of holding periods, market capitalization, volatility and other variables. Section five analyzes and discusses the empirical results. The last section provides some concluding remarks.

\section{Literature Review}

\subsection{Efficient Markets Hypothesis}

The classic definition of efficient markets hypothesis (EMH) is by Fama (1970). According to Fama, security prices always fully reflect all available information in an efficient market. As a result, one cannot consistently achieve returns exceeding average market returns on a risk-adjusted basis, given the information available at the time the investment is made. There are three major versions of the hypothesis: "weak", "semi-strong", and "strong". The weak form of the hypothesis claims that prices on traded assets already reflect all past publicly available information. The semi-strong form of the hypothesis claims that prices not only reflect all past publicly available information, but also instantly change to reflect new public information. The strong form of the hypothesis claims that prices instantly reflect all available information including past publicly available information, new public information and even hidden or "insider" information.

Sheilfer (2000) points out that EMH is based on three loosened-up assumptions. The first one is that investors are regarded as rational and they can give a reasonable valuation to the financial assets. Second, in some ways there are some investors who are irrational, but transactions among them occur randomly, sotheir irrationality will be counteracted and eventually prices will not be affected. Last, in some cases, those irrational investors will make the same mistake. However, there will be rational arbitragers in the market and those arbitragers will offset the influence brought by the irrational investors. That is to say, if rational investors exist in the market, the influence of irrational investors will be insignificant. The prices of financial assets will be set by rational investors and the market will become efficient.

After years of empirical study of EMH, some challenges appear. Behavioral economists attribute the imperfections in financial markets to a combination of cognitive biases such as overconfidence, overreaction, representative bias, information bias and various other predictable human errors in reasoning and information processing (Kahneman \& Tversky, 1979; Hogarth \& Reder 1987; Tversky \& Kahneman, 1992). They indicate that investors are not entirely rational and they depart from rationality not occasionally but frequently and make the same mistake that deviates from rationality. Furthermore, rational arbitragers cannot completely eliminate the influence on prices brought by the irrational investors' errors.

\subsection{Disposition Effect}

Based on Kahneman and Tversky's (1979) prospect theory (Note 1), Shefrin and Statman (1985) first defined the 'disposition effect', which is the tendency of investors to sell stocks with gains and hold stocks with losses. In 
other words, there is a disposition to sell 'winners' and hold 'losers'. Their study shows that, on average, investors' trades exhibit this disposition effect.

Odean (1998) (Note 2) studied 10,000 individual investors' trading records from 1987 through 1993 in US stock market and found that over the period of 1 or 2 years, investors could gain more profit from the winner stock that were sold than the loser stock which were held. Investors had the tendency to be risk averse for "winners" and risk-seeking for "losers". Nicholas and Wei (2009) have noted that the disposition effect is not a rational sort of conduct because of the nature of continuity of stock performance. That is to say, if the stock has been profitable over past couple of months, it will keep doing well in the next couple of months, and vice versa. This being the case, the rational act would be "to hold on to stocks that have recently risen in value; and to sell stocks that have recently fallen in value. But individual investors tend to do exactly the opposite.

Empirically, Brown et al. (2006) obtained the stock transaction data from 1995 and 2000 in Australian Stock Exchange and find that the investors are reluctant to crystallize losses and more eager to realize gains. Their study shows that the disposition effect is prevalent across retail, institutional and foreign investors in the Australian stock market. Gunesh and Merlin (2008) analyzed the presence of the disposition effect for 90,244 French individual investors between 1999 and 2006. Their study shows that the disposition effect is observable among French investors.

Another school of researchers are trying to explore the reasons that drive this irrational behavior. Frino et al. (2015) obtained 46,289 accounts which have had at least one trade from a leading Australian retail brokerage house for the period 2010 to 2012. In the study, they further split the investors into two groups: Chinese/non-Chinese heritage. They find that investors from Chinese group suffered a deeper degree of the disposition effect. In other words, culture plays a role in the investment behavior. Newton et al. (2013) devised an experiment by employing computer program to simulate the stock market. They split the investor into two groups: experienced investors and inexperienced undergraduates. They find that though both groups show the disposition effect, the more experienced and sophisticated investors demonstrate lower level of loss aversion and are less affected. .

There is some literature dedicated to studying China Stock Market. Visaltanachoti, Luo, and Lu (2007) find that the disposition effect is prevalent in A-shares market through 1996 to 2003. Chi and Zhuang (2011) indicate that the disposition effect in A-shares market reversed since 2006 because of the split-share structure reform. However, both of them agree that the disposition effect seems to be vague in B-shares market.

\section{Data and Measurement}

Daily information of all stock trading on Shenzhen and Shanghai Stock Exchanges, covering the period of January 2010 to December 2014, was obtained from CSMAR database. In order to examine the disposition effect and the house money effect in the stock markets, the data obtained includes stock codes, trade dates, daily closing prices, daily trading volume, daily turnover rate, outstanding shares and daily return rate. A total of 11462 observations were obtained and studied.

Following Atkins and Dyl (1997), the average holding period of firm i for each year is computed by dividing the number of outstanding shares in the firm by the firm's annual trading volume. Therefore, for the year $t$ the average holding period (in years) for the firm i's common stock is measured as follows:

$$
H P_{i, t}=\frac{\sum_{d=1}^{N} \text { Shares Outs } \tan \operatorname{ding}_{i, t, d} / \text { Volu }_{i, t, d}}{N}
$$

Where Shares Outstanding $\mathrm{i}_{\mathrm{t}, \mathrm{d}}$ is the shares outstanding on stock $\mathrm{i}$ in day $\mathrm{d}$ of year $\mathrm{t}, \mathrm{Volu}_{\mathrm{i}, \mathrm{t}, \mathrm{d}}$ is the respectively daily trading shares for year and $\mathrm{N}$ is the total number of trading days of stock i during year $\mathrm{t}$.

According to Visaltanachoti, Luo, and Lu (2007), the regression employed to examine the relation between investors' holding periods and the illiquidity so as to examine the disposition effect is:

$$
H P_{i, t}=\beta_{0}+\beta_{1} R E T_{i, t}+\beta_{2} I_{L L I Q_{i, t}}+\beta_{3} M V_{i, t}+\beta_{4} \text { Volatility }_{i, t}+\beta_{5} A_{\text {Dummy }}+\varepsilon_{i, t}
$$

Where $\mathrm{HP}_{\mathrm{i}, \mathrm{t}}$ is the average length of time that investors hold the stock of firm i during year $\mathrm{t}$ and ILLIQ $\mathrm{Q}_{\mathrm{i}, \mathrm{t}}$ is the calculated value from another model, which represents the average ratio of the daily absolute return to the trading volume on that day. Other control variables include $\mathrm{MV}_{\mathrm{i}, \mathrm{t}}$ which is firm i's average market value during year $t$ and Volatility $y_{i, t}$ which is the variance of firm's daily stock returns.

This current study follows the research by Chi and Zhuang (2011), with the fundamental purpose of examining 
the relation between investors' holding periods and stock returns. So, according to them, there are three reasons for not directly adopting the above model. First, the research purpose is different. In the research by Visaltanacholti, Luo, and $\mathrm{Lu}$ (2007), the purpose is to examine the relation between holding periods and illiquidity and this study is to focus on the relation between holding periods and stock returns. Second, because of the difference in research purpose, the variable ILLIQ in the above model would be meaningless in this study. Third, in the above model, the dummy variable $\mathrm{A}_{\text {Dummy }}$ is introduced in order to discuss the difference caused by different kinds of stocks. In this study, A-shares market, B-shares market and growth enterprise market (GEM) will become three samples and perform regression testing respectively. Therefore, the dummy variable $A_{\text {Dummy }}$ would also be meaningless in this study. In conclusion, the above model will be simplified as this:

$$
H P_{i, t}=\alpha+\beta_{1} \operatorname{Cap}_{i, t}+\beta_{2} R_{i, t}+\beta_{3} \operatorname{Vol}_{i, t}+\beta_{4} \operatorname{Tur}_{i, t}+\varepsilon_{i, t}
$$

In Equation 3, the explaining variable $\mathrm{Cap}_{\mathrm{i}, \mathrm{t}}$ is the tradable market capitalization of firm $\mathrm{i}$ in year $\mathrm{t}$, which reflects the scale of the firm. Market capitalization is related to the stock's liquidity, and furthermore, it is widely believed that expected returns on stock are negatively related to market capitalization (Banz, 1981; Reinganum, 1981; Fama \& French, 1992). Thus, introducing market capitalization into the regression can control the influence of return-size effect (Visaltanachoti, Luo, \& $\mathrm{Lu}, 2007$ ). Variable $\mathrm{R}_{\mathrm{i}, \mathrm{t}}$ indicates the average daily rate of return of stock $i$ of year $t$. In order to examine the relation between holding periods and stock returns, $R_{i, t}$ is the key variable and we expect an inverse relation between them. $V l_{i, t}$ represents the average return volatility of the stock and high return volatility reflects strong information asymmetry as well as short holding periods. If high volatility of stock returns results from high frequency of trading, we have the reason to expect a negative coefficient of $\mathrm{Vol}_{\mathrm{i}, \mathrm{t}}$

\section{Summary Statistics}

Table 1 presents the summary statistics for the common stock in Chines Stock market during 2010-2014. The data is computed on the basis of more than 1 million observations obtained from CSMAR database.

Table 1. Description statistics of primary variables

\begin{tabular}{ccccccc}
\hline Year & $\begin{array}{c}\text { NO. of } \\
\text { Firms }\end{array}$ & $\begin{array}{c}\text { Average Holding } \\
\text { Periods (Days) }\end{array}$ & $\begin{array}{c}\text { Average Market } \\
\text { Capitalization (Yuan) }\end{array}$ & $\begin{array}{c}\text { Weighted Average } \\
\text { Annual Rate of Return }\end{array}$ & $\begin{array}{c}\text { Average Return } \\
\text { Volatility }\end{array}$ & $\begin{array}{c}\text { Average Daily } \\
\text { Turnover Rate }(\%)\end{array}$ \\
\hline 2010 & 1787 & 65.27 & $5.459 * 10^{9}$ & 1.215 & $5.59 * 10^{-3}$ & 4.86 \\
2011 & 2127 & 86.53 & $7.455^{*} 10^{9}$ & -0.005 & $2.77 * 10^{-3}$ & 4.14 \\
2012 & 2408 & 172.47 & $8.090 * 10^{9}$ & -0.203 & $1.46 * 10^{-3}$ & 2.85 \\
2013 & 2563 & 213.23 & $6.740 * 10^{9}$ & 0.078 & $3.90^{*} 10^{-3}$ & 2.29 \\
2014 & 2577 & 145.92 & $7.432 * 10^{9}$ & 0.089 & $1.21 * 10^{-3}$ & 2.41 \\
\hline
\end{tabular}

Note. The weighted average annual rate of return is weighted by the tradable market capitalization of each stock and dividends investment has been considered when computing the annual rate of return.

The average market capitalization of the listed Chinese firms reached its peak at 8090 million Yuan in 2012. After that, it experienced a dramatic drop to 6740 million Yuan in 2013. Finally the figure rebounded to 7432 million Yuan in 2014. With the Chinese stock markets taken as a whole, the average holding periods are shortest in 2010 with a positive weighted average annual rate of return as well as the largest average return volatility. In 2011 and 2012, the average holding periods become longer with negative annual rates of return. Especially in 2012, the holding periods are more than twice that of 2010. The figures in these two years indicate the disposition effect in the overall Chinese stock markets that investors prefer to keep losers. Meanwhile, the figures of 2010 and 2014 reflect the characteristics of the disposition effect that investors prefer to sell winners. However, it is rather strange that the average holding periods in 2013 are the longest while it has a positive average rate of return, which is contradictory to the disposition effect. In 2014, the average holding periods become shorter again with a positive rate of return but still much longer than the figure of 2010 and 2011.

Overall, judging from the data of the first three years, the disposition effect is observed to different degrees in the whole Chinese stock markets. Nevertheless, the correlation between the gain or loss of an individual stock and its holding periods still needs to be further examined. The disposition effect in each segmented market will also be examined in the next section. The difference in the holding periods between the winner stocks and the loser stocks can directly reflect the characteristic of the disposition effect of investors, which is of huge significance to discussing investors' risk preference and behavioral biases. 


\section{Empirical Results and Analysis}

\subsection{Annual Holding Period Regression}

Table 2. Cross-sectional regression for stock holding periods

\begin{tabular}{|c|c|c|c|c|c|}
\hline & 2010 & 2011 & 2012 & 2013 & 2014 \\
\hline \multicolumn{6}{|c|}{ Panel A: A-shares market } \\
\hline$\alpha$ & $78.250^{* * * *}$ & $79.318^{* * *}$ & $129.594 * * *$ & $186.554 * * *$ & $145.877^{* * *}$ \\
\hline Cap & $1.15 * 10^{-9 * * *}$ & $3.07 * 10^{-9} * * *$ & $5.91 * 10^{-9} * * *$ & $8.38 * 10^{-9} * * *$ & $6.11 * 10^{-9} * * *$ \\
\hline $\mathrm{R}$ & -4.831 & $-8.898 *$ & 12.448 & -27.802 & -7.437 \\
\hline Vol & 35.534 & $279.153 * *$ & -80.112 & $105.680 * *$ & 105.075 \\
\hline Tur & $-491.347 * * *$ & $-721.852 * * *$ & $-1003.166^{* * *}$ & $-2547.567 * * *$ & $-2629.379 * * *$ \\
\hline R-squared & 0.014 & 0.644 & 0.747 & 0.706 & 0.734 \\
\hline \multicolumn{6}{|c|}{ Panel B: B-shares market } \\
\hline$\alpha$ & $421.679 * * *$ & $673.269 * * *$ & $1014.031 * * *$ & $1603.405^{* * *}$ & $1057.511 * * *$ \\
\hline Cap & $5.06 * 10^{-9}$ & $4.01 * 10^{-9}$ & $2.93 * 10^{-9}$ & $-1.43 * 10^{-8}$ & $1.82 * 10^{-8}$ \\
\hline $\mathrm{R}$ & $39.100 * *$ & 68.033 & -145.430 & 87.400 & $199.258 * *$ \\
\hline Vol & 19350.19 & 64352.09 & 7032.055 & 56903.54 & -4083.780 \\
\hline Tur & $-30527.14 * * *$ & $-60784.99 * * *$ & $-78724.79 * * *$ & $-220640.1 * * *$ & $-120363.8 * * *$ \\
\hline R-squared & 0.547 & 0.575 & 0.181 & 0.406 & 0.353 \\
\hline \multicolumn{6}{|c|}{ Panel C: Growth Enterprise market } \\
\hline$\alpha$ & $12.756^{* * *}$ & $26.552 * * *$ & $57.847 * * *$ & $101.228 * * *$ & $78.678^{* * *}$ \\
\hline Cap & $1.53 * 10^{-9} * * *$ & $1.59 * 10^{-9} * *$ & $1.32 * 10^{-8 * * *}$ & $2.81 * 10^{-9}$ & $3.63 * 10^{-9} * * *$ \\
\hline $\mathrm{R}$ & -0.275 & $3.922 * *$ & $-15.256^{*}$ & $11.292 *$ & $3.154^{*}$ \\
\hline Vol & -4.504 & -3.941 & 398.254 & $4221.563 * *$ & $-13019.84 * * *$ \\
\hline Tur & $-28.187 * * *$ & $-79.752 * * *$ & $-243.861 * * *$ & $-914.810^{* * *}$ & $-572.760^{* * *}$ \\
\hline R-squared & 0.843 & 0.554 & 0.391 & 0.519 & 0.614 \\
\hline
\end{tabular}

Note. $\alpha$ represents the constant estimation. $* * *, * *$ and $*$ denote significant levels at $1 \%, 5 \%$ and $10 \%$, respectively. Explanatory variable includes Cap, the average market capitalization; R, the weighted average annual rate of return; Vol, the average return volatility of the stock; and TUR, the average daily turnover rate.

The regression results for all firms on A-shares market, B-shares market and Growth Enterprise market are respectively reported in Panel A, Panel B and Panel C of Table 2. The General least squares method is used.

In Panel A, the estimation results of the A-shares market, the regression coefficients on the annual return are negative in 2010, 2011, 2013 and 2014. However, only in 2011, the coefficient is statistically significant which indicates that the disposition effect exists in the A-shares market in that year. The coefficients on the tradable market capitalization are positively significant in all the years, which illustrates that investors holding periods for common stocks in A-shares market are positively associated with the market capitalization of the firms. Investors prefer larger firms in A-shares market when they are making investment decision. We don't find the expected negative coefficients of volatility in the five years. Instead, these coefficients are positive and statistically significant in 2011 and 2014 in Panel A, which indicate that investors in these two years are risk-seeking to the return volatility. Overall, the R square for A- shares from 2010-2014 range from 0.014 to 0.747 , indicating a strong power of overall model explanation.

Among the estimation results of the B-shares in the Chinese stock markets in Panel B, two regression coefficients on the annual return are significant and positive in 2010 and 2014, showing that investors of B-shares market are risk-seeking after gains and prefer to hold winner stocks for a longer period. Except 2012, the coefficients of annual return are all positive in the other four years. Even in year 2012, the negative coefficient is not statistically significant. We therefore argue that there is a lack of strong evidence to support the existence of the disposition effect in the B-shares market. This suggests a different behavior between institutional investors and individual local investors as B-shares market are dominated by institutional investors. Unlike the results in Panel A, none of the five coefficients on the tradable market capitalization in Panel B has been found to be both positive and significant, which means that investors of B-shares market do not have a special preference to those large firms. The R-squared ranges from 0.18 to 0.575 for B-shares market.

The estimation results of growth enterprise market are reported in Panel C. The coefficients on the annual return in 2011, 2013 and 2014 are positively significant and only in 2012, the coefficient is negatively significant. This 
result suggests that investors in Growth Enterprise market are more willing to hold winner stocks longer. The disposition effect only exists in Growth Enterprise market in 2012.

The regression results reported above suggest that the disposition effect exists in A-shares market and Growth Enterprise market for only one year respectively and there is no evidence to prove that the disposition effect exists in B-shares market. For B-shares market, because of the regulations on exchange control and high transaction costs, institutional investors are still the dominant investors. Generally they are more rational and more risk-seeking to return than individual investors. For A-shares market and Growth Enterprise market, a possible reason for the infrequent existence of the disposition effect is that investment experience can alleviate investors' behavioral biases to some extent in stock markets. (Zhang \& Liu, 2013) As mentioned above, the experienced and skillful investors in growth enterprise market tend to be risk-seeking after gains and prefer to hold winner stocks longer. Through years of development in the Chinese stock markets, not only the investors in Growth Enterprise market but also a rather large proportion of investors in A-shares market have accumulated much investment experience and become more skillful. Such experience makes Chinese investors become more rational and more risk-seeking towards returns of an individual stock.

Most of the coefficients of Cap are positive and significant in A-shares market and Growth Enterprise market, indicating that investors' holding periods of a stock increase with the company's scale in these two markets. The coefficients of Tur are all negative and significant in all of the markets, showing that the higher turnover rate of a stock, the shorter holding period of a stock is.

\section{Conclusion}

\subsection{Summary of Conclusions}

This study investigates average holding periods, market capitalization, stock returns, return volatility and turnover rate for the Chinese stock markets from 2010 to 2014. It also examines the disposition effect in the Chinese stock markets empirically. The main research results are as follows:

First, according to the data analysis, investors in A-shares market and Growth Enterprise market have a special preference for stocks with larger market capitalizations. They are more willing to hold those large firms' stocks for longer periods. However, investors in B-shares market do not show such a preference. The reason may be the differences of the types of investors. Although local investors have been allowed to trade in B-shares market since 2001, because of the regulations on exchange control and high transaction costs, B-shares market is still dominated by institutional investors, while A-shares market and Growth Enterprise market are dominated by individual investors. Different types of investors show different preferences for different variables.

Second, the disposition effect exists in A-shares market and growth enterprise market in 2010 and in B-shares market in 2014. In the other years, there is no strong evidence to support the disposition effect in any Chinese stock market. And in some years of Growth Enterprise market and B-shares market, the opposite of disposition effect is even at work. It is suggested that investor sophistication and trading experiences play an important role in the nonexistence of the disposition effect especially in Growth Enterprise market. Because of the time requirement in Growth Enterprise market, investors of Growth Enterprise market are assumed to be skillful and experienced, thus they are more rational and risk-seeking to returns, which corresponds to the regression results. For B-shares market, the dominance of institutional investors affects the disposition effect since institutional investors are generally more rational than individual investors.

Last, macro-economic factors still have an influence on investors' attitude towards risk although the influence has been weakened. According to the study of Chi and Zhuang (2011), after the split-share structure reform in 2006, investors of A-shares market become more rational and more willing to hold the winner stocks for longer periods as well as being risk-seeking when faced with gains. In this study, with the exception of the year 2011, none of the coefficients on the $\mathrm{R}$ variable in A-shares market is both negative and significant to holding periods, which may be the result of the influence of the reform. Unlike the results of Chi and Zhuang (2011), no opposite of disposition effect appeared, which reflects that the influence of macro-economic factors may be weakened in the last few years.

\section{References}

Atkins, A. B., \& Dyl, E. A. (1997). Transaction Costs and Holding Periods for Common Stocks. Journal of Finance, (52), 309-25. https://doi.org/10.1111/j.1540-6261.1997.tb03817.x

Banz, R. W. (1981). The Relation between Return and Market Value of Common Stocks. Journal of Financial Economics, (9), 3-18. https://doi.org/10.1016/0304-405X(81)90018-0 
Barbeirs, N., \& Huang, M. (2001). Mental Accounting, Loss Aversion, and Individual Stock Returns. Journal of Finance, (56), 1247-92. https://doi.org/10.1111/0022-1082.00367

Barberis, N., \& Xiong, W. (2009). What Drives the Disposition Effect? An Analysis of a Long-Standing Preference-Based Explanation. The Journal of Finance, (64), 751-784. https://doi.org/10.1111/j.1540-6261.2009.01448.x

Barberis, N., Huang, M., \& Santos, T. (2001). Prospect Theory and Asset Prices. Quarterly Journal of Economics, (116), 1-53. https://doi.org/10.1162/003355301556310

Boolell, G. S., \& Merlin, M. (2008). Are French Individual Investors reluctant to realize their losses? SSRN Electronic Journal. Retrieved from http://ssrn.com/abstract=1282119

Brown, P., Chappel, N., Rosa, R. D. S., \& Walter, T. (2006). The Reach of the Disposition Effect: Large Sample Evidence across Investor Classes. International Review of Finance, (6), 43-78. https://doi.org/10.1111/j.1468-2443.2007.00059.x

Chi, L. X., \& Zhuang, X. (2011). Investors’ Behavioral Biases and Stop-Loss Strategy: Empirical Study Based on Disposition Effect and Reference Point. Journal of Management Sciences in China, 14(10), 54-66.

Chi, L. X., Zhuang, X. T., \& Wang, J. (2008). Study of Investor's Disposition Effect in China Using IPO Trading Volume. Chinese Journal of Management, 5(1), 118-123.

Da Costa, N., Goulart, M., Cupertino, C., Macedo, J., \& Da Silva, S. (2013). The Disposition Effect and Investor Experience. Journal of Banking \& Finance, (37), 1669-1675. https://doi.org/10.1016/j.jbankfin.2012.12.007

Fama, E. F., \& French, K. R. (1992). The Cross Section of Expected Stock Returns. Journal of Finance, (47), 427-65. https://doi.org/10.1111/j.1540-6261.1992.tb04398.x

Frino, A., Lepone, G., \& Wright, D. (2015). Investor characteristics and the disposition effect. Pacific-Basin Finance Journal, (31), 1-12. https://doi.org/10.1016/j.pacfin.2014.10.009

Hogarth, R. M., \& Reder, M. W. (1987). Rational Choice: The Contrast between Economics and Psychology. Chicago: University of Chicago Press.

Johnson, E., \& Thaler, R. (1990). Gambling with the House Money and Trying to Break Even: The Effect of Prior Outcomes on Risky Choice. Management Science, (36), 643-60.

Kahneman, D., \& Tversky, A. (1979). Prospect Theory: An Analysis of Decision under Risk. Econometrica, (46), 171-185. https://doi.org/10.2307/1914185

Li, X. L., \& Zhang, W. X. (2005). The Effectiveness Research of Evaluation of SMEs Growth. Modern Economic Science, 27(5), 76-80.

Odean, T. (1998). Do Investors Trade Too Much? American Economic Review, (89), 1279-1298. https://doi.org/10.2139/ssrn.94143

Reinganum, M. R. (1981). Misspecification of Capital Asset Pricing: Empirical Anomalies based on Earnings Yields and Market Values. Journal of Finance, (9), 19-46. https://doi.org/10.1016/0304-405X(81)90019-2

Shefrin, H., \& Statman, M. (1985). The Disposition to Sell Winners Too Early and Ride Losers Too long; Theory and Evidence. Journal of Finance, (40), 777-90. https://doi.org/10.1111/j.1540-6261.1985.tb05002.x

Shleifer, A. (2000). Inefficient Markets: An Introduction to Behavioral Finance. Oxford University. https://doi.org/10.1093/0198292279.001.0001

Thaler, R. (1980). Toward a Positive Theory of Consumer Choice. Journal of Economic Behavior and Organization, (1), 39-60. https://doi.org/10.1016/0167-2681(80)90051-7

Tversky, A., \& Kahneman, D. (1992). Advances in Prospect Theory: Cumulative Representation of Uncertaintly. Journal of Risk and Uncertaintly, 5(4), 297-323. https://doi.org/10.1007/BF00122574

Visaltanachoti, N., Luo, H., \& Lu, L. (2007). Holding Periods, illiquidity and disposition effect in the Chinese stock markets. Applied Financial Economics, (17), 1265-1274. https://doi.org/10.1080/09603100600905053

Zhang, C. X., Liu, C., \& Liao, L. (2013). What are the Factors that Induce the Irrational Behaviors. Statistical Research, 30(8), 93-101.

Zhang, Z., \& Xu, X. Z. (2006). Behavioral Finance Research Summary. Management World, (9), 155-167. 


\section{Notes}

Note 1. Under the prospect theory, people are believed to be more concerned about the gains or losses brought by a certain decision making

Note 2. In odean's study, he proposed two forms of gain and loss respectively, which are realized gain, realized loss and paper gain, paper loss. Realized gain and realized loss refers to stock sold by investors. To compare the selling price of the stock with the reference purchasing price, gains or losses can be ensured in this way

\section{Copyrights}

Copyright for this article is retained by the author(s), with first publication rights granted to the journal.

This is an open-access article distributed under the terms and conditions of the Creative Commons Attribution license (http://creativecommons.org/licenses/by/4.0/). 